\title{
(WHY) DO WE NEED CORPORATE TAXATION?
}

\author{
ALFONS J. WEICHENRIEDER
}

CESIFO WORKING PAPER NO. 1495

CAtegory 1: Public Finance

JULY 2005

An electronic version of the paper may be downloaded

- from the SSRN website:

www.SSRN.com

- from the CESifo website:

www.CESifo.de 


\title{
(WhY) DO WE NEED CORPORATE TAXATION?
}

\begin{abstract}
Tax rates on corporate income have considerably come down in the process of tax competition and further pressures are evident. Against this background, the paper discusses possible benefits of corporate income taxation that may be at risk. In particular, the paper surveys the empirical evidence for a backstop function of the corporate income tax that allows preserving individual taxes.
\end{abstract}

JEL Code: H25.

Keywords: tax competition, corporate taxation.

\author{
Alfons J. Weichenrieder \\ Johann Wolfgang Goethe University \\ Faculty of Economics and Business Administration \\ 60054 Frankfurt (Main) \\ Germany \\ a.weichenrieder@em.uni-frankfurt.de
}

I am grateful to Sijbren Cnossen, Gaëtan Nicodeme, and other participants of the OeNB Workshop on "Capital Taxation after EU-Enlargement" in January 2005 for helpful discussions and to Tina Klautke for careful research assistance. 


\section{The Corporate Income Tax: An Endangered Species?}

The question of why we need a tax on corporations would receive much less attention if it were not that many economists and politicians believe that this tax is on the endangered species list. If it is relevant to tax competition and a race to the bottom, we should expect to see results in the area of corporate taxation. This largely represents a source based taxation of mobile capital, the type of taxation that is bound to vanish completely in standard theoretical models of tax competition among small jurisdictions.

Figure 1: Average Corporate Tax Rates (1985 to 2004)

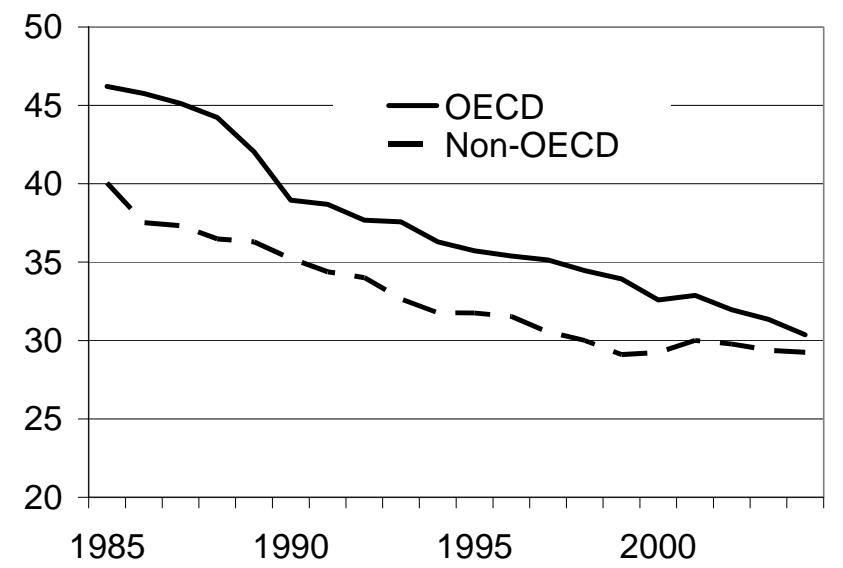

Note: The dashed line represents the mean corporate income tax rate in up to 45 non-OECD countries, the normal line represents the average for up to 29 OECD countries. The rates include average local taxes plus federal rates on retained earnings.

Source: PricewaterhouseCoopers, KPMG, Office of Tax Policy Research (University of Michigan).

Looking at the rates of corporate taxes around the world, a downward trend is clearly visible for both OECD countries and other countries. For OECD countries, the average rate in the mid 1980s was around 45 percent, while in 2004 it came down to some 30 percent. Extrapolating this linear trend implies that tax rates will come down to zero by the middle of the century. 
Figure 2: Corporate Tax Rates and Country Size (2002)

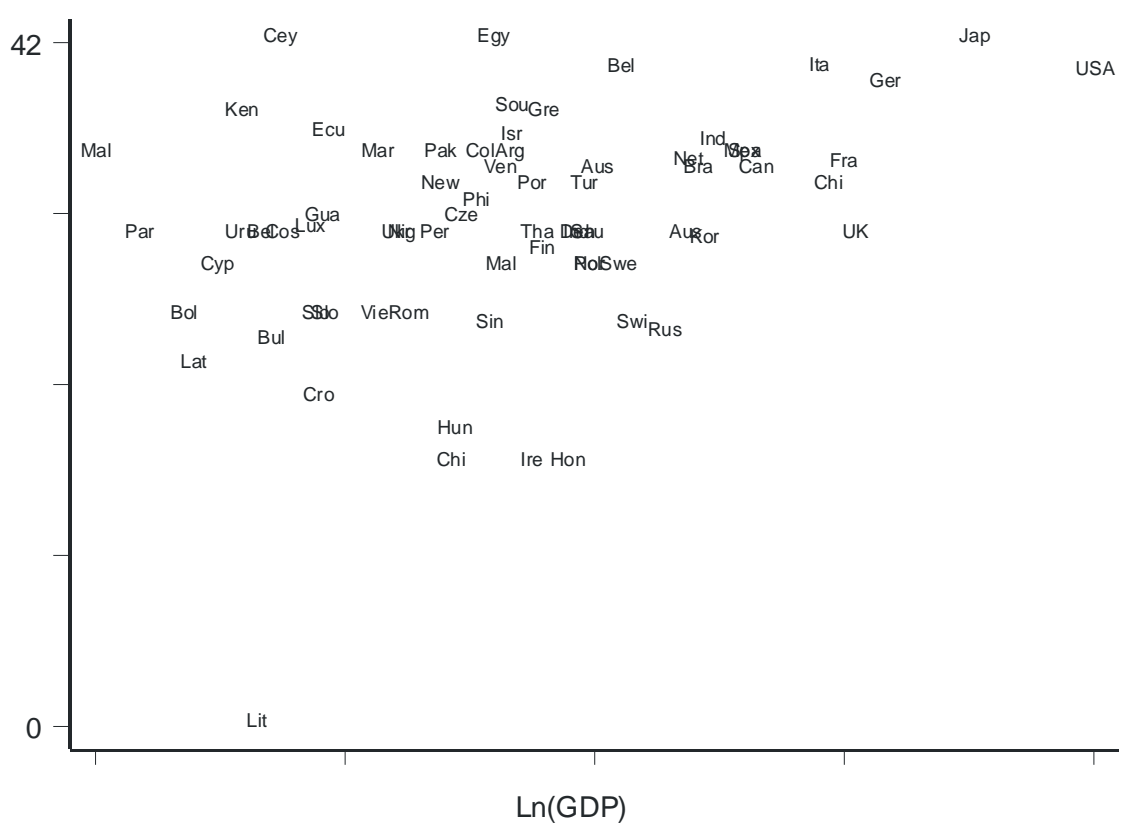

Source: PricewaterhouseCoopers, KPMG, Office of Tax Policy Research (University of Michigan), Worldbank Economic Indicators.

It is not only that empirically rates have declined in the process of globalization. The empirical evidence also supports tax competition models in their prediction that smaller countries should have lower rates than larger countries. ${ }^{1}$ The reason for this prediction is that small countries have much more elastic tax bases. In these countries, tax reductions can attract a huge amount of new capital but they cost little in terms of less tax revenue from the small existing stock of capital. Conversely, large countries have a large stock of capital and, to compensate for the revenue loss from old capital, reducing rates must attract much more new capital. This is an economic explanation for the well-known fact that in general tax havens are small. Figure 2 illustrates the correlation between statutory tax rates and the logarithm of GDP for the year 2002 on a broader basis of 70 countries. The positive correlation turns out to be highly statistically significant.

\footnotetext{
${ }^{1}$ See Bucovetsky (1991), Wilson (1991), Wellisch (2000), Haufler (2004) or, for the case of sales taxes, Kanbur and Keen (1993).
} 
Figure 3: Corporate Tax Revenues in OECD Countries

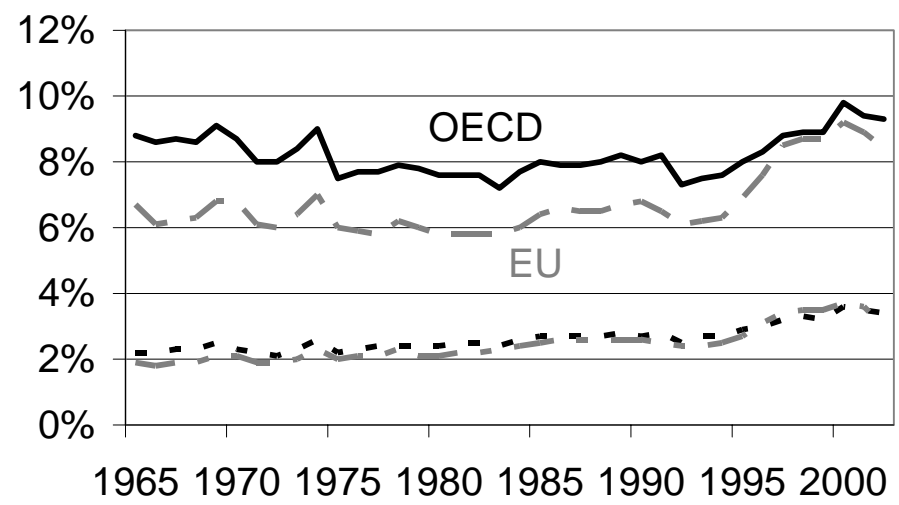

Note: $\quad$ The upper two lines measure the unweighted average of tax revenues as a fraction of total tax revenues. The two lower lines show the ratio of corporate taxes to GDP in OECD and EU countries.

Source: OECD Revenue Statistics.

However, the picture given by the observed tax rates across time and across countries may not give the whole story. A possible counter argument against the vanishing corporate tax hypothesis is that, while rates have decreased empirically, tax revenues derived from corporate taxes on average have become quite stable in the OECD countries. ${ }^{2}$ This fact is illustrated by Figure 3. The upper two lines reflect the average ratio of corporate tax revenues to total tax revenues in OECD and EU countries. For the OECD as a whole, the long run average figure is eight per cent of total tax revenues. The lower lines give the average ratios when GDP is the denominator. From this overall picture there is little evidence that tax competition has eroded corporate taxes. A possible explanation is that the efforts to broaden the tax base by cutting exemptions and depreciation have more than compensated the cuts in tax rates. The empirical development may simply be a reflection of a levelling of the playing field rather than evidence of tax competition.

\footnotetext{
${ }^{2}$ For a similar observation see Devereux, Griffith and Klemm (2002).
} 


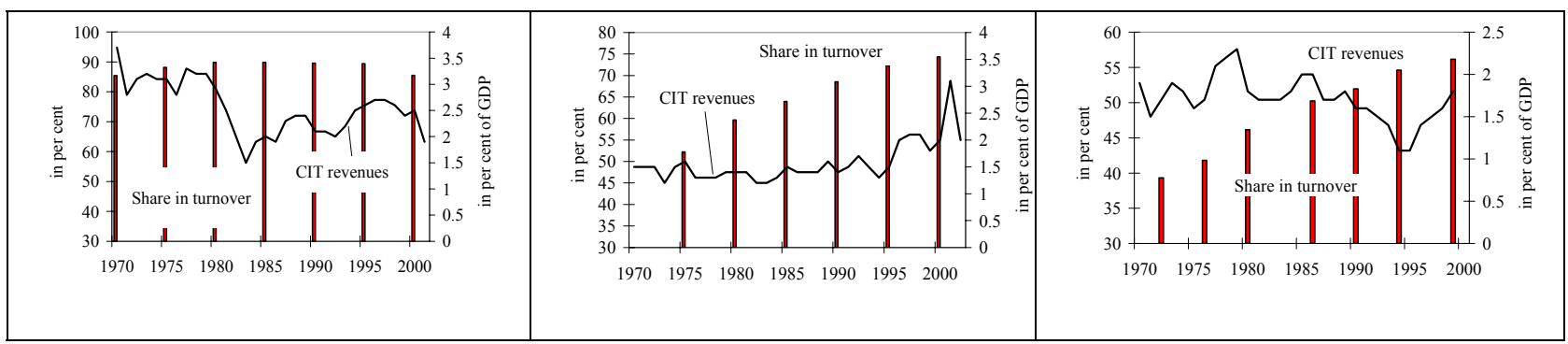

Note: In each of the graphs, the line represents the corporate income tax revenues as a fraction of GDP, measured on the right hand scale. The columns depict the share of turnover of incorporated businesses measured on the left hand scale.

Source: OECD Revenue Statistics, US Census Bureau, Bundesanstalt Statistik Österreich, Statistisches Bundesamt.

On the other hand, base broadening may not have occurred only because of active policy measures. It may also be a side effect of an underlying time trend. Such a time trend could reflect the fact that more and more enterprises have to incorporate if they are to carry out their business more efficiently. Unfortunately, only a few countries have official statistics that make it possible to evaluate the existence of such an empirical trend. Figure 4 depicts three exceptions: Germany, Austria, and the US. In each of the graphs, the line represents the corporate income tax revenues as a fraction of GDP, measured on the right hand scale. The columns depict the share of turnover of incorporated businesses, which is plotted against the left hand scale. Since the early 1970 s, corporate tax revenues as a fraction of GDP have come down in the US, have increased in Austria and have stayed roughly constant in Germany. The development in Austria and Germany that illustrates a sharply increasing role for corporations makes it particularly clear that, by looking at the development of revenues, the role of corporations relative to non-incorporated businesses should be kept in mind. The observation of a nearly constant revenue-to-GDP ratio is not sufficient to dismiss a race to the bottom. The 
increased role of corporations in Germany and Austria (and presumably in other countries) seems to blur the footprints of tax competition on the revenue side. ${ }^{3}$

Additional evidence that the picture given by tax revenues is distorted comes from forward looking measures of effective taxation as calculated by Devereux, Griffith and Klemm (2002). The authors clearly show that the effective average taxation of corporate profits, as implied by the tax codes, has decreased since the 1980s in most countries. These forward looking measures of the tax burden are in line with empirical evidence for U.S. multinationals: over the years the average tax on a dollar of income earned by subsidiaries around the world has declined (Altshuler, Grubert and Newlon 2001).

So yes, from the evidence presented above, corporate income tax does look like an endangered species. This brings up the natural next question: what would be the costs if we were to lose this tax instrument in the process of tax competition? To address this question in the next sections we will review the various arguments that have been put forward to justify a corporate income tax.

\section{The Arguments for a Corporate Income Tax}

\subsection{The Corporate Income Tax as a Benefit Tax?}

Like individuals, corporations certainly profit from the legal system, the public infrastructure and public security. So why shouldn't they pay taxes just like individuals? One answer is that corporations are owned by individuals who already are subject to taxation. Therefore taxing corporations separately implies a double burden. Another counter argument against using the corporate income tax as a benefit tax is that there are usually other, more targeted, instruments available for internalizing the cost of providing public inputs (Mintz

\footnotetext{
${ }^{3}$ A similar argument was made recently by Peter Birch Sörensen at the 2001 meeting of the German Economic
} 
1995). If corporations eject dirty water and air, then it is better, and normally possible, to tax these unwanted activities directly. If corporations congest roads by using trucks, then a toll or a gasoline tax is the adequate answer.

Even if we came to the conclusion that those more direct instruments are unavailable, several problems with a corporate income tax as a benefit tax remain. Why should it be a sensible application of the benefit principle that a highly leveraged corporation, which, because of the tax deductibility of interest payments, has lower profits than an equity-financed corporation, should pay fewer benefit taxes? The crowding caused by a company truck is hardly dependent on the way it is financed. Even worse, it is not even related to the profits before interest and tax.

An argument proposed by legal scholars, but sometimes also considered by economists (Meade 1978, p. 145), is that limited liability, which is a result of incorporation, is a benefit that justifies special benefit taxation. This argument overlooks the fact that it is only in some settings that limited liability is an advantage. When a business partner is contracting with a limited liability corporation the partner will be well aware of the potential loss from a nonperforming corporation. The partner could therefore offer better conditions to an individual entrepreneur who offers unlimited liability and therefore a lower chance of default. An entrepreneur therefore bears a cost of incorporating that will internalize a sizeable fraction of possible external costs. External cost of incorporation may prevail if there is a non-market relationship. For example, a corporation may take higher environmental risks if it is isolated from the possible cost by limited liability. But again, the adequate reaction to this problem would be a regulation against excessive risk taking, e.g. compulsory insurance for environmental hazards, rather than a general corporate income tax.

Association, but without supporting evidence. 


\subsection{The Corporate Income Tax as a Tax on Foreigners?}

When Bill Clinton ran for his first U.S. presidency in the early 1990s, a mocking phrase that was used to describe his tax agenda was: "don't tax you, don't tax me, tax the guy from overseas." In fact, a tax that falls on voters outside the own constituency is politically tempting and the corporate tax may be used as an instrument for "tax exporting". Expressing it less negatively, it can be argued that a corporate tax is necessary to make sure that foreign owners of domestic corporations pay taxes in the host country of a foreign-owned corporation.

In some cases the cost of the tax on foreigners is minimal. This applies where the home country of a multinational allows a tax credit for taxes paid abroad. Some part, or even all, of the taxes levied in the host country may be refunded in the home country of a multinational. For this reason, a tax increase may not turn away foreign investors: the tax is like a free lunch. The argument for a corporate tax may also be strong in cases where foreigners are able to earn a pure economic rent. Insofar as the corporate tax is a tax on those pure rents, adverse investment reactions will also be absent.

Empirical studies, however, have made it clear that the free lunch hypothesis is only a faint approximation of reality. In reality, higher taxes do turn away foreign investors (see the survey by Ederveen and de Mooij 2001), although tax elasticities may be even larger if home countries exempt foreign income instead of using a tax credit to alleviate double taxation (Desai, Foley and Hines 2003).

The tax exporting motive is not completely absent when countries make their corporate tax decisions. A recent study by Huizinga and Nicodeme (2003) shows that countries with a large fraction of foreign-owned corporations tend to have a higher corporate tax than other countries. Nevertheless, if tax exporting was the main driving force in international tax competition, it would be hard to reconcile it with the observed downward trend in corporate 
taxation. Moreover, tax exporting measures that discriminate against foreigners may come under the scrutiny of the EU Court of Justice and this may limit their applicability.

\subsection{The Corporate Income Tax as a Prepayment of Income Taxes}

Once we dismiss the idea of a corporate tax as a benefit tax, the rationale for a separate corporate tax largely vanishes. But we may still want to keep the corporate tax as a withholding device for the personal income tax. Ideally, the corporate tax should then reflect the personal tax rates of the owners of a corporation. This idea has been argued strongly by Engels and Stützle (1968) who suggested a system in which retained and distributed earnings of a corporation are effectively taxed at the personal tax rates of its shareholders. Corporate tax schemes that have been implemented in practice have been somewhat less ambitious. A real world corporate tax system that comes closest to the withholding idea is a full imputation system that aligns the corporate tax rate with the (top) personal income tax rate. When a dividend is paid by the corporation, the underlying corporate taxes are credited against the personal taxes of the shareholder. If the credit exceeds the personal tax that is due on the dividend income, there is a tax refund. If the corporation retains part of its earnings, then the effective tax on this part of its earnings reflects at least the personal income tax rate for those investors that are in the highest personal income tax bracket.

Globalization has brought up several problems for such a scheme. A first issue is that cross border ownership of shares makes it difficult to align the corporate tax rate with the investors' top personal tax rates. When investors come from different countries, there are different top personal rates. Even worse, countries may refuse to grant a tax credit for cross-border dividends. If the credit is given by the host country of the corporation, this implies that fewer or no taxes are collected on corporate profits when there is foreign ownership. Conversely, if 
the credit is given by the home country of the investor, then this country has to give a credit for taxes that another country has levied. In a recent ruling, the European Court of Justice (ECJ) has condemned exactly this latter reluctance and found that the corresponding asymmetry in the Finnish rules is in contradiction with the right of free capital movements. ${ }^{4}$ Under the Finnish imputation system, a tax credit for underlying corporate taxes is granted to a Finnish personal tax payer if the dividend is paid by a Finnish corporation but is refused if the dividend is paid by a corporation from another EU member state.

If a government is reluctant to refund corporate taxes that have been charged by other governments, the easiest way to react to the ECJ decision is to abolish imputation. Therefore, the ECJ decision seems to be the formal death sentence for imputation systems within Europe. The abolition of the imputation system in Germany for fiscal years after 2000 already anticipated this ruling. An "appeal" against this death sentence required multilateral coordination to implement a system of mutually extended tax credits.

\subsection{A Safeguard against Erosion of Personal Capital Taxation}

Although globalization and European integration have made integration of corporate and personal tax systems more difficult, other reasons to stick to corporate taxation prevail. As long as countries continue to tax personal capital income there will be a demand for instruments that prevent evasion and avoidance. The European Directive on Interest Income (2003/48/EEC) can be seen as such an instrument: capital income should not be exempt simply because it derives from a foreign rather than a domestic bank account. Leaving corporate income untaxed, while taxing personal capital income would generate another loophole.

\footnotetext{
${ }^{4}$ ECJ decision of September 7, 2004 (C 319/02).
} 
Indeed there is empirical evidence that this loophole is important. Several studies on US time series data (see Mackie-Mason and Gordon 1997, Gordon and MacKie-Mason 1994a, Goolsbee 1998) show that the decision to incorporate is significantly related to the difference between the income tax rates on personal and corporate income, and a recent study using cross section tax differentials among U.S. states points in the same direction (Goolsbee 2004).

Empirical evidence is also presented in Fuest and Weichenrieder (2002). The paper uses panel data on 13 countries and looks at the fraction of total savings that occurs in the corporate sector. The study finds that a one percentage point increase in the difference between the top personal income tax rate and the corporate tax rate increase the fraction of savings that occur in the corporate sector by some 2 per cent.

Figure 5: Cuts in Top Personal Tax Rates and Corporate Tax Rates (1985-1999)

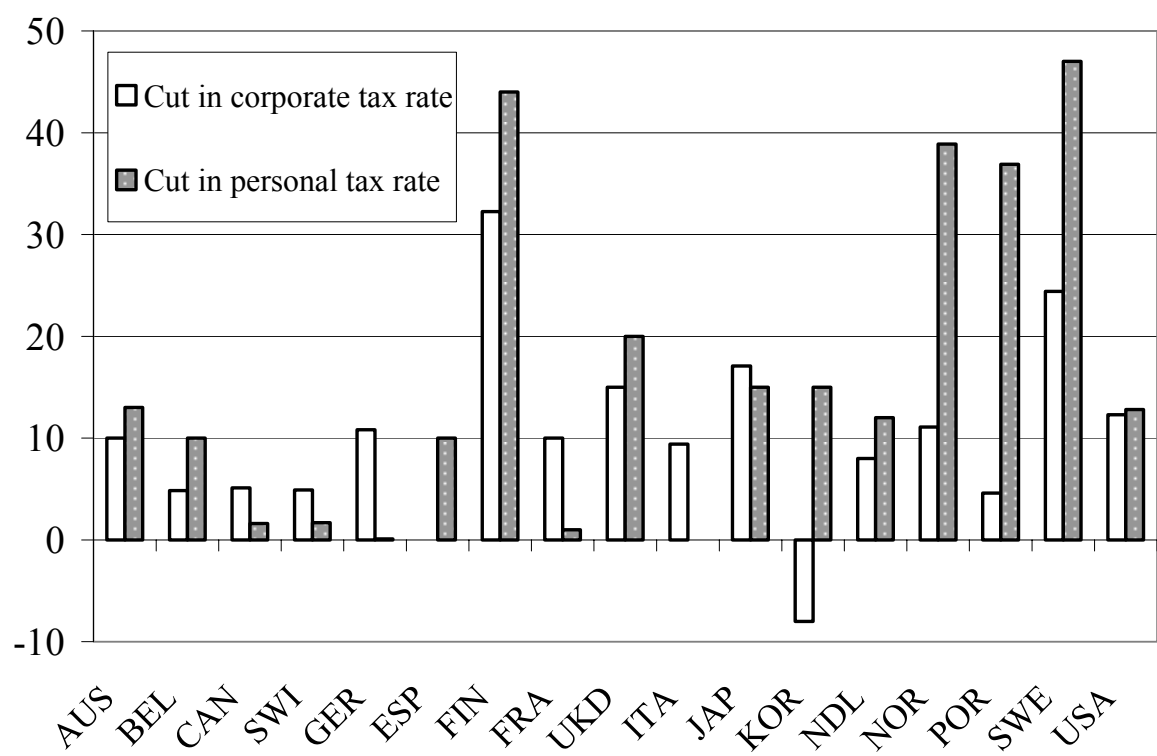

Note: The cuts in personal tax rates between 1985 and 1999 refer to the top personal tax rate that is applicable to interest income. The rates for Switzerland (SWI) refer to Zurich, the rates for the U.S. refer to the state New York. 
Table 1: The Vanishing of the Comprehensive Personal Income Tax

\begin{tabular}{|c|c|c|}
\hline Country & 1985 & 2002 \\
\hline Austria & & $\mathrm{I} / \mathrm{D}$ \\
\hline Belgium & $\mathrm{I} / \mathrm{D}$ & $\mathrm{I} / \mathrm{D}$ \\
\hline Canada & & $\mathrm{D}$ \\
\hline Denmark & & $\mathrm{D}$ \\
\hline Finland & & $\mathrm{I} / \mathrm{D} / \mathrm{P}$ \\
\hline France & I & I \\
\hline Germany & & $\mathrm{HK}$ \\
\hline Greece & & $\mathrm{I} / \mathrm{D}$ \\
\hline \multicolumn{3}{|l|}{ Ireland } \\
\hline Italy & $\mathrm{I}$ & I \\
\hline Japan & $\mathrm{I} / \mathrm{D}$ & $\mathrm{I} / \mathrm{D}$ \\
\hline Luxembourg & & $\mathrm{HK}$ \\
\hline Netherlands & & $\mathrm{I} / \mathrm{D} / \mathrm{P}$ \\
\hline Norway & & $\mathrm{I} / \mathrm{D} / \mathrm{P}$ \\
\hline Portugal & & $\mathrm{I} / \mathrm{D}$ \\
\hline \multicolumn{3}{|l|}{ Spain } \\
\hline Sweden & & $\mathrm{I} / \mathrm{D} / \mathrm{P}$ \\
\hline \multicolumn{3}{|l|}{ Switzerland } \\
\hline UK & & \\
\hline USA & & \\
\hline
\end{tabular}

The empirical evidence suggests that the decline in corporate tax rates may bring up problems in the taxation of personal capital income. For tax reasons, savers may prefer corporations rather than bank accounts if the corporate rates fall well below the personal rates. It is unclear, however, whether such a gap between personal and corporate tax rates is developing. As illustrated by Figure 5, in many OECD countries, cuts in top personal tax rates on interest income have been even more pronounced than cuts in corporate tax rates. To some part this reflects a shift in income tax systems. While in 1985 a large majority of OECD countries used a comprehensive income tax under which all incomes were taxed at the same rate, many countries have changed to separate taxation of various income types with lower rates on interest income. Table 1 gives a picture of the vanishing comprehensive income tax that is associated with this development by comparing the years 1985 and 2002. Countries marked with an $I$ have a system that uses a scheduled tax on personal interest income. In the 
case of a $D$ or a $P$, dividends/profits fall under a flat rate that is lower than the top income tax rate on labor income. The remaining shaded fields indicate countries that used a comprehensive system in the respective year. In some countries in this latter group only half of a received dividend is included in the personal tax base. This is denoted by $H K$.

The fact that in many countries tax rates on personal capital income have decreased by more than the rates on corporate income may hint at tax competition effects that are even more pronounced for the personal income tax than for the corporate income tax. Slemrod (2002, p. 1182) finds that, depending on the details of his exploratory regressions, the decline in personal tax rates can explain a large fraction of the decline in international corporate tax rates.

\subsection{A Safeguard against Erosion of Personal Labor Taxation}

Although the corporate income tax is a tax on capital and not on labor, it may act as an important instrument for protecting labor taxation from erosion. If tax policy implements different rates on different income baskets, tax payers are tempted to relabel income that falls in the high tax basket in order to shift it into the low tax one. Empirically, these incentives may be important. Gordon and Slemrod (2000) find that, for the US, a one percentage point increase in the difference between the corporate and personal taxes increases reported labor income by some 3\%. In a similar vein, evidence from Norway provided by Fjaerli and Lund (2001) shows that the reduced rate on capital income significantly increased dividends and reduced wages of manager owners. Since the study by Fjaerli and Lund looks at a time period before Norway adapted a formal income splitting rule to avoid income shifting between 
baskets, it is difficult to say whether this result of huge income shifting is generally valid for dual income tax systems. ${ }^{5}$

It should be noted that a corporate income tax is just one way to curb income shifting. Alternatively, a cash flow tax on pure economic rents could be used to do the same job. The reason is that the instrument for curbing income shifting does not necessarily have to raise income on intra marginal units of capital invested. It is sufficient that a marginal Euro shifted from the labor income basket to the corporate income basket is taxed the same in the two baskets and therefore that shifting brings no tax savings. ${ }^{6}$ In addition, more analysis on the Nordic models of income splitting would be welcome to see whether income shifting can be effectively curbed in the face of differing tax rates on labor and capital income.

\section{Conclusion}

Corporate income taxes in OECD countries account for some 8 per cent of total tax revenues. From the point of view of a treasury department, this may suffice to conclude that the corporate tax is needed. In this paper I have discussed some more subtle reasons that may justify a corporate tax. Several studies have pointed out that the corporate income tax may have an important backstop function that helps preserve the tax base of other taxes and the erosion of the corporate tax in the process of tax competition may therefore have severe additional effects.

The importance of the backstop function for capital taxation in general largely depends on whether capital taxation continues to be demanded in the first place. If the answer is yes, then reduced corporate taxes, keeping other taxes on capital constant, seem to lead to sizable

\footnotetext{
5 A dual income tax system combines progressive taxation of labor income with a low flat rate on capital income.

${ }^{6}$ Given that the tax on corporations is expected to raise revenues, a pure cash flow tax may be more vulnerable to international income shifting by multinational firms via transfer pricing than a corporate income tax. See Gordon/MacKie-Mason (1994b) and Haufler/Schjelderup (2000).
} 
income shifting towards the corporate sector and away from the higher taxed sectors. The importance of the corporate tax as a backstop for labor taxation largely depends on the functioning of alternative measures to avoid income shifting. More empirical analysis in this area would be very welcome. 


\section{References}

Altshuler, R., H. Grubert and T.S. Newlon (2001), "Has US Investment abroad Become more sensitive to Tax Rates?", in: J.R. Hines (ed.) International Taxation and Multinational Activity. Chicago: University of Chicago Press, 9-32.

Bucovetsky, S. (1991), "Asymmetric Tax Competition", Journal of Urban Economics 30, 167-181.

Desai, M.A., C.F. Foley, and J.R. Hines (2003), "Chains of Ownership, Regional Tax Competition, and Foreign Direct Investment," in: H. Herrmann und R. Lipsey (eds.), Foreign Direct Investment in the Real and Financial Sector of Industrial Countries. Berlin: Springer, 61-98.

Devereux, M.P., R. Griffith and A. Klemm (2002), "Corporate Income Tax Reforms and International Tax Competition", Economic Policy 35, 451-495.

Ederveen, S. and R. de Mooij (2001). Taxation and Foreign Direct Investment: a Metaanalysis. Quarterly Review of CPB Netherlands Bureau for Economic Policy Analysis.

Engels, W. and W. Stützel (1968), Teilhabersteuer. Ein Beitrag zur Vermögenspolitik zur Verbesserung der Kapitalstruktur und zur Vereinfachung des Steuerrechts. Frankfurt a.M.

Fjaerli, E. and D. Lund (2001), "The Choice between Owner's Wages and Dividends under the Dual Income Tax", Finnish Economic Papers 14, 104-119.

Fuest, C. and A.J. Weichenrieder (2002), "Tax Competition and Profit Shifting: On the Relationship between Personal and Corporate Tax Rates", Ifo Studien 48, 611-632.

Goolsbee, A. (1998), Taxes, Organizational Form, and the Deadweight Loss of the Corporate Income Tax, Journal of Public Economics 69, 143-152.

Goolsbee, A. (2004), "The Impact of the Corporate Income Tax: Evidence from State Organizational Form Data", Journal of Public Economics 88, 2283-2299.

Gordon, R.H. and J.K. MacKie-Mason (1994a), "Tax Distortions to the Choice of Organizational Form", Journal of Public Economics 55, 279-306.

Gordon, R.H. and J.K. MacKie-Mason (1994b), "Why is there Corporate Income Taxation in a Small Open Economy? The Role of Transfer Pricing and Income Shifting, in: M. Feldstein and J. Hines (eds.), Issues in International Taxation. Chicago: University of Chicago Press, 67-91.

Gordon, R.H. and J. Slemrod (1998), "Are 'real' Responses to Taxes Simply Income Shifting between Corporate and Personal Tax Bases?", in: J. Slemrod (ed.), Does Atlas Shrug? The Economic Consequences of Taxing the Rich. Cambridge: Harvard University Press, 240280.

Haufler, A. (2004), Taxation in a Global Economy. Cambridge: Cambridge University Press.

Haufler, A. and G. Schjelderup (2000), Corporate Tax Systems and Cross Country Profit Shifting, Oxford Economic Papers 52, 306-325.

Huizinga, H. and G. Nicodeme (2003), Foreign Ownership and Corporate Income Taxation: An Empirical Evaluation, CEPR Discussion Paper 3952.

Kanbur, R. and M. Keen (1993), "Jeux sans fontieres: Tax Competition and Tax Coordination when Countries Differ in Size", American Economic Review 83, 877-892.

MacKie-Mason, J.K. and R.H. Gordon (1997), "How much Do Taxes Discourage Incorporation?" Journal of Finance 52, 477-505.

Meade, J. (1978), The Structure and Reform of Direct Taxation, the Meade Report. Boston: Allen \& Unwin.

Mintz, J. (1995), "The Corporation Tax", Fiscal Studies 16, 23-68. 
Slemrod, J. (2004), "Are Corporate Tax Rates, or Countries, Converging?" Journal of Public Economics 88, 1169-1186.

Wellisch, D. (2000), Theory of Public Finance in a Federal State. Cambridge: Cambridge University Press.

Wilson, J.D. (1991), "Tax Competition with Interregional Differences in Factor Endowments", Regional Science and Urban Economics 21, 423-451. 


\section{CESifo Working Paper Series}

(for full list see www.cesifo-group.de)

1429 Sören Blomquist and Luca Micheletto, Optimal Redistributive Taxation when Government's and Agents' Preferences Differ, March 2005

1430 Olof Åslund and Peter Fredriksson, Ethnic Enclaves and Welfare Cultures - QuasiExperimental Evidence, March 2005

1431 Paul De Grauwe, Roberto Dieci and Marianna Grimaldi, Fundamental and NonFundamental Equilibria in the Foreign Exchange Market. A Behavioural Finance Framework, March 2005

1432 Peter Egger, Stefan Gruber, Mario Larch and Michael Pfaffermayr, Knowledge-Capital Meets New Economic Geography, March 2005

1433 George Economides and Apostolis Philippopoulos, Should Green Governments Give Priority to Environmental Policies over Growth-Enhancing Policies?, March 2005

1434 George W. Evans and Seppo Honkapohja, An Interview with Thomas J. Sargent, March 2005

1435 Helge Berger and Volker Nitsch, Zooming Out: The Trade Effect of the Euro in Historical Perspective, March 2005

1436 Marc-Andreas Muendler, Rational Information Choice in Financial Market Equilibrium, March 2005

1437 Martin Kolmar and Volker Meier, Intra-Generational Externalities and InterGenerational Transfers, March 2005

1438 M. Hashem Pesaran and Takashi Yamagata, Testing Slope Homogeneity in Large Panels, March 2005

1439 Gjermund Nese and Odd Rune Straume, Industry Concentration and Strategic Trade Policy in Successive Oligopoly, April 2005

1440 Tomer Blumkin and Efraim Sadka, A Case for Taxing Education, April 2005

1441 John Whalley, Globalization and Values, April 2005

1442 Denise L. Mauzerall, Babar Sultan, Namsoug Kim and David F. Bradford, Charging $\mathrm{NO}_{x}$ Emitters for Health Damages: An Exploratory Analysis, April 2005

1443 Britta Hamburg, Mathias Hoffmann and Joachim Keller, Consumption, Wealth and Business Cycles in Germany, April 2005 
1444 Kohei Daido and Hideshi Itoh, The Pygmalion Effect: An Agency Model with Reference Dependent Preferences, April 2005

1445 John Whalley, Rationality, Irrationality and Economic Cognition, April 2005

1446 Henning Bohn, The Sustainability of Fiscal Policy in the United States, April 2005

1447 Torben M. Andersen, Is there a Role for an Active Fiscal Stabilization Policy? April 2005

1448 Hans Gersbach and Hans Haller, Bargaining Power and Equilibrium Consumption, April 2005

1449 Jerome L. Stein, The Transition Economies: A NATREX Evaluation of Research, April 2005

1450 Raymond Riezman, John Whalley and Shunming Zhang, Metrics Capturing the Degree to which Individual Economies are Globalized, April 2005

1451 Romain Ranciere, Aaron Tornell and Frank Westermann, Systemic Crises and Growth, April 2005

1452 Plutarchos Sakellaris and Focco W. Vijselaar, Capital Quality Improvement and the Sources of Growth in the Euro Area, April 2005

1453 Kevin Milligan and Michael Smart, Regional Grants as Pork Barrel Politics, April 2005

1454 Panu Poutvaara and Andreas Wagener, To Draft or not to Draft? Efficiency, Generational Incidence, and Political Economy of Military Conscription, April 2005

1455 Maurice Kugler and Hillel Rapoport, Skilled Emigration, Business Networks and Foreign Direct Investment, April 2005

1456 Yin-Wong Cheung and Eiji Fujii, Cross-Country Relative Price Volatility: Effects of Market Structure, April 2005

1457 Margarita Katsimi and Thomas Moutos, Inequality and Relative Reliance on Tariffs: Theory and Evidence, April 2005

1458 Monika Bütler, Olivia Huguenin and Federica Teppa, Why Forcing People to Save for Retirement may Backfire, April 2005

1459 Jos Jansen, The Effects of Disclosure Regulation of an Innovative Firm, April 2005

1460 Helge Bennmarker, Kenneth Carling and Bertil Holmlund, Do Benefit Hikes Damage Job Finding? Evidence from Swedish Unemployment Insurance Reforms, May 2005

1461 Steffen Huck, Kai A. Konrad and Wieland Müller, Merger without Cost Advantages, May 2005 
1462 Louis Eeckhoudt and Harris Schlesinger, Putting Risk in its Proper Place, May 2005

1463 Hui Huang, John Whalley and Shunming Zhang, Trade Liberalization in a Joint Spatial Inter-Temporal Trade Model, May 2005

1464 Mikael Priks, Optimal Rent Extraction in Pre-Industrial England and France - Default Risk and Monitoring Costs, May 2005

1465 François Ortalo-Magné and Sven Rady, Heterogeneity within Communities: A Stochastic Model with Tenure Choice, May 2005

1466 Jukka Pirttilä and Sanna Tenhunen, Pawns and Queens Revisited: Public Provision of Private Goods when Individuals make Mistakes, May 2005

1467 Ernst Fehr, Susanne Kremhelmer and Klaus M. Schmidt, Fairness and the Optimal Allocation of Ownership Rights, May 2005

1468 Bruno S. Frey, Knight Fever - Towards an Economics of Awards, May 2005

1469 Torberg Falch and Marte Rønning, The Influence of Student Achievement on Teacher Turnover, May 2005

1470 John Komlos and Peter Salamon, The Poverty of Growth with Interdependent Utility Functions, May 2005

1471 Hui Huang, Yi Wang, Yiming Wang, John Whalley and Shunming Zhang, A Trade Model with an Optimal Exchange Rate Motivated by Current Discussion of a Chinese Renminbi Float, May 2005

1472 Helge Holden, Lars Holden and Steinar Holden, Contract Adjustment under Uncertainty, May 2005

1473 Kai A. Konrad, Silent Interests and All-Pay Auctions, May 2005

1474 Ingo Vogelsang, Electricity Transmission Pricing and Performance-Based Regulation, May 2005

1475 Spiros Bougheas and Raymond Riezman, Trade and the Distribution of Human Capital, June 2005

1476 Vesa Kanniainen, Seppo Kari and Jouko Ylä-Liedenpohja, The Start-Up and Growth Stages in Enterprise Formation: The "New View" of Dividend Taxation Reconsidered, June 2005

1477 M. Hashem Pesaran, L. Vanessa Smith and Ron P. Smith, What if the UK had Joined the Euro in 1999? An Empirical Evaluation Using a Global VAR, June 2005

1478 Chang Woon Nam and Doina Maria Radulescu, Effects of Corporate Tax Reforms on SMEs' Investment Decisions under the Particular Consideration of Inflation, June 2005 
1479 Panos Hatzipanayotou, Sajal Lahiri and Michael S. Michael, Globalization, CrossBorder Pollution and Welfare, June 2005

1480 John Whalley, Pitfalls in the Use of Ad valorem Equivalent Representations of the Trade Impacts of Domestic Policies, June 2005

1481 Edward B. Barbier and Michael Rauscher, Trade and Development in a Labor Surplus Economy, June 2005

1482 Harrie A. A. Verbon and Cees A. Withagen, Tradable Emission Permits in a Federal System, June 2005

1483 Hendrik Hakenes and Andreas Irmen, On the Long-Run Evolution of Technological Knowledge, June 2005

1484 Nicolas Schmitt and Antoine Soubeyran, A Simple Model of Brain Circulation, June 2005

1485 Carsten Hefeker, Uncertainty, Wage Setting and Decision Making in a Monetary Union, June 2005

1486 Ondřej Schneider and Jan Zápal, Fiscal Policy in New EU Member States - Go East, Prudent Man!, June 2005

1487 Christian Schultz, Virtual Capacity and Competition, June 2005

1488 Yvan Lengwiler and Elmar Wolfstetter, Bid Rigging - An Analysis of Corruption in Auctions, June 2005

1489 Johannes Becker and Clemens Fuest, Does Germany Collect Revenue from Taxing Capital Income?, June 2005

1490 Axel Dreher and Panu Poutvaara, Student Flows and Migration: An Empirical Analysis, June 2005

1491 Bernd Huber and Marco Runkel, Interregional Redistribution and Budget Institutions under Asymmetric Information, June 2005

1492 Guido Tabellini, Culture and Institutions: Economic Development in the Regions of Europe, July 2005

1493 Kurt R. Brekke and Michael Kuhn, Direct to Consumer Advertising in Pharmaceutical Markets, July 2005

1494 Martín Gonzalez-Eiras and Dirk Niepelt, Sustaining Social Security, July 2005

1495 Alfons J. Weichenrieder, (Why) Do we need Corporate Taxation?, July 2005 